\title{
Penerapan Model Pembelajaran Kooperatif Tipe Role Playing untuk Meningkatkan Hasil Belajar Siswa Kelas X AP1 Pada Pelajaran PPKn
}

\author{
Nyoman Kertia \\ SMK Negeri 1 Sukasada \\ e-mail: kertianym11@gmail.com
}

\begin{abstract}
Abstrak
Penelitian ini bertujuan meningkatkan hasil belajar mata pelajaran PPKn siswa kelas $X$ AP1 SMK Negeri 1 Sukasada semester genap tahun pelajaran 2017/2018 dengan penerapan model pembelajaran Kooperatif tipe Role playing. Jenis penelitian ini adalah Penelitian Tindakan Kelas (PTK). Penelitian dilaksanakan sebanyak 2 siklus. Subyek penelitian adalah siswa kelas X AP1 SMK Negeri 1 Sukasada tahun pelajaran 2017/2018 semester genap yang berjumlah 30 orang. Data dianalisis menggunakan kuantitaif dan kualitatif. Berdasarkan hasil penelitian didapatkan terjadi peningkatan hasil belajar PPKn siswa siklus 1 dengan materi "Wawasan Nusantara dalam konteks Negara kesatuan Republik Indonesia" pada siklus I dengan rata-rata sebesar 74,8 yang termasuk ke dalam kategori kurang, sedangkan ketuntasan klasikal sebesar $30 \%$. Sedangkan pada materi yang sama siklus II rata-rata PPKn siswa sebesar 85,81 yang termasuk klasifikasi baik, dan ketuntasan klasikal sebesar $100 \%$ dari 30 siswa. Dari analisis data di atas model pembelajaran kooperatif tipe Role Playing terbukti efektif dalam meningkatkan hasil belajar siswa.
\end{abstract}

Kata Kunci: Hasil Belajar PPKn, Model Pembelajaran Kooperatif tipe Role Playing

\begin{abstract}
This study aims to improve the learning outcomes of PPKn subjects in class X AP1 of SMK Negeri 1 Sukasada in the even semester of the school year 2017/2018 with the application of a Role-type Cooperative learning model. This type of research is Classroom Action Research (CAR). The study was conducted in 2 cycles. The subjects of the study were class X AP1 SMK Negeri 1 Sukasada in 2017/2018 academic year consist of 30 people. Data were analyzed using quantitative and qualitative. Based on the results of the study it was found that there was an increase in the learning outcomes of PPKn students in cycle 1 with the material "Insights Nusantara in the context of the Unitary State of the Republic of Indonesia "in the first cycle with an average of 74.8 which is included in the less category, while the classical completeness is $30 \%$. Whereas in the same material the second cycle the average PPKn of students was 85.81 which included good classification, and classical completeness of $100 \%$ of 30 students. From the data analysis above the cooperative learning model of the Role Playing proved to be effective in improving student learning outcomes.
\end{abstract}

Kata Kunci: PPKn learning result, cooperative learning model Role Playing 


\section{Pendahuluan}

Pendidikan merupakan suatu kegiatan yang kompleks, berdimensi luas, dan banyak variabel yang mempengaruhi keberhasilan penyelenggaraannya. Pendidikan diharapkan mampu membentuk sumber daya manusia yangberkualitas dan mandiri, serta memberi dukungan dan perubahan untuk perkembangan masyarakat, bangsa, dan negara Indonesia. Pendidikan merupakanhal penting dalam kehidupan setiap individu. Hal ini dijelaskan dalam Undangundang No.20 Tahun 2003 pasal 1, tentang Sistem Pendidikan Nasional(Sisdiknas) yang menjelaskan bahwa pendidikan adalah usaha sadar dan terencana untuk menghidupkan suasana belajar dan proses pembelajaran agar siswa secaraaktif mengembangkan potensi dirinya untuk memiliki kekuatan spiritualkeagamaan, pengendalian diri, kepribadian, kecerdasan, akhlak mulia, sertaketerampilan yang diperlukan dirinya dan masyarakat, bangsa, dan negara. Pengertian tersebut dapatlah dimengerti bahwa pendidikan merupakan suatu usaha atau aktivitas untuk membentuk manusia-manusia yang cerdas dalam berbagai aspeknya baik intelektual, sosial, emosional maupun spiritual, terampil serta berkepribadian dan dapat berprilaku dengan dihiasi akhlak mulia. Ini berarti bahwa dengan pendidikan diharapkan dapat terwujud suatu kualitas manusia yang baik dalam seluruh dimensinya, baik dimensi intel ektual, emosional, maupun spiritual yang nantinya mampu mengisi kehidupannya secara produktif bagi kepentingan dirinya dan masyarakat. Menurut Sari (2017) belajar merupakan usaha seseorang yang dilakukan secara sadar dan menghasilkan perubahan di dalam dirinya, sebagai hasil pengalamannya sendiri dalam berinteraksi dengan lingkungannya. Sedangkan hasil belajar merupakan Kemampuan siswa yang dicapai setelah mengikuti proses belajar mengajar yang mengakibatkan adanya perubahan, disebabkan karena telah mencapai penguasaan materi yang telah diberikan dalam proses belajar mengajar.

PPKn merupakan mata pelajaran yang berperan penting dalam pembentukan karakter sebagai individu dan warga negara yang berkualitas. Winataputra, dkk (2008: 1.1) mengungkapkan bahwa PKn merupakan pengembangan pendidikan demokrasi yang mengemban tiga fungsi pokok, yaitu kecerdasan warga negara, tanggung jawab warga negara, dan partisipasi warga negara. Warga negara yang baik bukan hanya dalam dimensi rasional, melainkan dimensi spiritual, emosional dan sosial sehingga setiap individu memiliki karakter dan bersifat multidimensional.

Berdasarkan hasil pengamatan guru pada saat mengajar, guru sebagai pengajar di kelas terkesan kurang memahami kurikulum 2013 di dukung pula dengan fakta di lapangan guru masih terkesan memberikan model pembelajaran yang masih bersifat konvensional yaitu menggunakan metode ceramah hal ini menyebabkan aktivitas belajar dan kreatifitas belajar siswa tidak nampak karena proses pembelajaran hanya berpusat pada guru (teacher centered), hal ini sejalan dengan temuan dalam penelitian yang dilakukan oleh Lestari (2014), dimana guru sering menggunakan suatu model pembelajaran konsenvional yaitu model tradisional dalam pengajaran yang selalu menggunakan metode ceramah dan tanya jawab tanpa menggunakan media sehingga proses belajar anak hanya sekedar merekam informasi saja, hal demikian mengakibatkan proses belajar anak hanya bersifat harfiah saja. Guru mendiktekan semua informasi dan murid memperhatikaan serta mencatat yang pada akhirnya anak membiasakan diri untuk tidak kreatif dalam mengemukakan ide-ide dan memecahkan masalah yang efeknya akan membawa anak dalam kehidupan di masyarakat. Siswa kurang dapat mengolah informasi menjadi ide-ide baru, tetapi hanya merekam dan mengemukanan informasi yang telah diterimanya. Selain itu dari hasil pengamatan peneliti ada beberapa kelemahan dari model pembelajaran konvensional yang biasa peneliti lihat saat proses pembelajaran pendidikan pancasila dan kewarganegaraan di kelas yakni: 1) Pelajaran berjalan membosankan, 2) Siswa menjadi pasif dan hanya menulis saja, 3) Karena siswa pasif maka pengetahuan yang di peroleh mudah dilupakan, 4) Siswa hanya belajar dengan cara menghapal dan tanpa memahami makna dari pembelajaran itu sendiri

Untuk mengatasi berbagai temuan di atas, diperlukan pembelajaran yang dapat membuat keaktifan dan meningkatkan hasil belajar siswa Diharapkan guru menerapkan pendekatan model Role Playing, menurut Tuken (2016) pada dasarnya mata pelajaran PKn merupakan pelajaran yang menyenangkan jika disajikan dengan metode yang tepat. Mengingat PKn adalah Mata pelajaran yang menekankan pada pengembangan nilai, moral, dan etika maka dalam pembelajaran perlu diterapkan model Role Playing. Model ini mengarahkan siswa untuk mengkreasi peristiwa sejarah atau kejadian yang akan muncul pada era globalisasi. Menurut Hamalik (2008:214) melalui Role Playing siswa dapat bertindak dan mengekspresikan perasaan serta pendapat tanpa kekhawatiran mendapat sanksi. Selain itu bermain peran 
memungkinkan para siswa mengidentifikasi situasi-situasi dunia nyata dengan ide-ide orang lain. Menurut Nuliandini (2016) Metode Role Play merupakan metode yang dapat mendorong para siswa untuk memerankan, mendramatisasikan, dan melihat secara langsung situasi yang terkait dengan masalahmasalah, tanpa menggunakan naskah tertulis untuk kemudian mendiskusikan masalah-masalah tersebut. Metode ini membantu siswa untuk lebih memahami dan menganalisis per-masalahan sosial karena dalam prosesnya mereka terlibat dan melihat secara langsung bagaimana permasalahan tersebut diselesaikan. Menurut Kristin (2018) Ada banyak model pembelajaran yang dapat digunakan guru untuk membantu dalam proses pembelajaran.

Salah satu model itu adalah model Role Playing atau bermain peran. Model pembelajaran Role Playing merupakan salah satu model yang dapat diterapkan dalam proses pembelajaran di dalam kelas karena model ini menarik bagi siswa, mereka dapat bermain peran sebagai tokoh dalam peristiwa sejarah atau kejadian-kejadian masa lampau. Menurut Nurhasanah (2016) Role playing merupakan suatu metode pembelajaran yang mengajak siswa untuk terlibat langsung dalam pembelajaran, penguasaan bahan pelajaran berdasarkan pada kreatifitas serta ekspresi siswa dalam meluapkan imajinasinya terkait dengan bahan pelajaran yang ia dalami tanpa adanya keterbatasan kata dan gerak, namun tidak keluar dari bahan ajar. Menurut Tarigan (2016) Model pembelajaran bermain peran (Role Playing) merupakan salah satu model pembelajaran sosial, yaitu suatu model pembelajaran dengan menugaskan siswa untuk memerankan suatu tokoh yang ada dalam materi atau peristiwa yang diungkapkan dalam bentuk cerita sederhana. Menurut Yanto (2015) bermain peran (Role Playing) adalah cara menyajikan suatu bahan pelajaran atau materi pelajaran dengan mempertunjukkan, mempertontonkan, atau memperlihatkan suatu keadaan atau peristiwa-peristiwa yang dialami orang, cara atau tingkah laku dalam hubungan sosial. Menurut Ernani (2016) Metode Role Playing merupakan dimana siswa bisa berperan atau memainkan peranan dalam dramatisasi masalah sosial/psikologis. Metode Role Playing atau bermain peran adalah metode pembelajaran sebagai bagian dari simulasi yang diarahkan untuk mengkreasi peristiwa sejarah, mengkreasi peristiwa-peristiwa aktual, atau kejadian-kejadian yang mungkin muncul pada masa mendatang. Adapun prosedur yang terdapat dalam metode role playing, seperti yang dipaparkan dalam penelitian Dewi (2014) yaitu: a) menentukan topik; b) memilih para pelaku; c) menentukan jalan cerita; d) pelaksanaan kegiatan role playing; e) mendiskusikan permainan; f) penilaian terhadap kegiatan yang dilakukan; g) membuat kesimpulan dan saran dari kegiatan Role Playing. Dalam proses penelitian yang berlangsung selama dilapangan, tentunya takaran sebuah penelitian PTK harus berjalan baik sesuai prosedur siklus dalam rujukan teori, dalam penelitian ini peneliti menggunakan 2 siklus karena dirasakan cukup efektif melihat perkembangan siswa dalam hal hasil belajar dan aktivitas belajar. Hasil belajar dalam penelitian ini dikatakan berhasil karena mengalami peningkatan berangsur selama dua siklus dan juga aktivitas bertambah meningkat pada siklus dua.

Dari penyampaian gagasan dan permasalahan yang tertuang dalam latar belakang, penelitian ini nantinya akan menggunakan metodologi penelitian kualitatif deskriptif yang pada umumnya sudah sering digunakan dalam Penelitian-penelitian Tindakan Kelas (PTK) agar peneliti dalam hal ini sesuai dengan prosedur kajian ilmiah yang sudah di validkan dalam model-model penelitian sehingga menghasilkan suatu data yang sistematis dan prosedural untuk meneliti di SMK Negeri 1 Sukasada, Subjek yang diteliti dalam metodologi yang akan diterapkan di sekolah yaitu siswa kelas X Akomodasi Perhotelan I, dengan jumlah 36 siswa dengan sumber data yakni primer.

Melihat kenyataan tersebut, maka peran guru sebagai pendidik perlu mendapatkan perhatian khusus di dalam penerapan model pembelajaran yang tepat, karena dengan penerapan model pembelajaran yang tepat akan dapat memacu semangat para siswa dalam mengikuti pembelajaran dan mendorong siswa mengembangkan pengetahuan yang dimiliki dengan pengetahuan yang didapatkan dari sekolah sehingga para siswa akan bersikap aktif dalam mengikuti pelajaran khususnya pelajaran PPKn. Sesuai dengan masalah tersebut, maka saya sebagai peneliti akan mencoba melakukan penelitian dengan judul penerapan model pembelajaran kooperatif tipe Role Playing untuk meningkatkan hasil belajar siswa kelas $\mathrm{X}$ AP1 pada pelajaran PPKn di SMK Negeri 1 Sukasada Tahun pelajaran 2017/ 2018. 


\section{Metode}

Penelitian ini termasuk ke dalam Penelitian Tindakan Kelas (PTK). PTK bertujuan untuk mewujudkan proses penelitian yang mempunyai manfaat ganda baik bagi peneliti yang dalam hak ini mereka memperoleh informasi yang berkaitan dengan permasalahan, maupun pihak subjek yang diteliti dalam mendapatkan manfaat langsung dari adanya tindakan nyata (Darmadi, 2011: 246).

Dalam penelitian tindakan kelas ini dilaksanakan sebanyak dua siklus dengan masingmasing siklus terdiri dari dua kali pertemuan. Masing-masing siklus terdiri dari empat tahapan, yaitu: (1) Rencana tindakan, (2) Pelaksanaan tindakan, (3) observasi/evaluasi, dan (4) reflekasi. Pelaksanaan PTK dapat dilihat pada gambar 1.

Sebagai berikut Agar lebih jelas, dapat di lihat pada gambar di bawah ini:

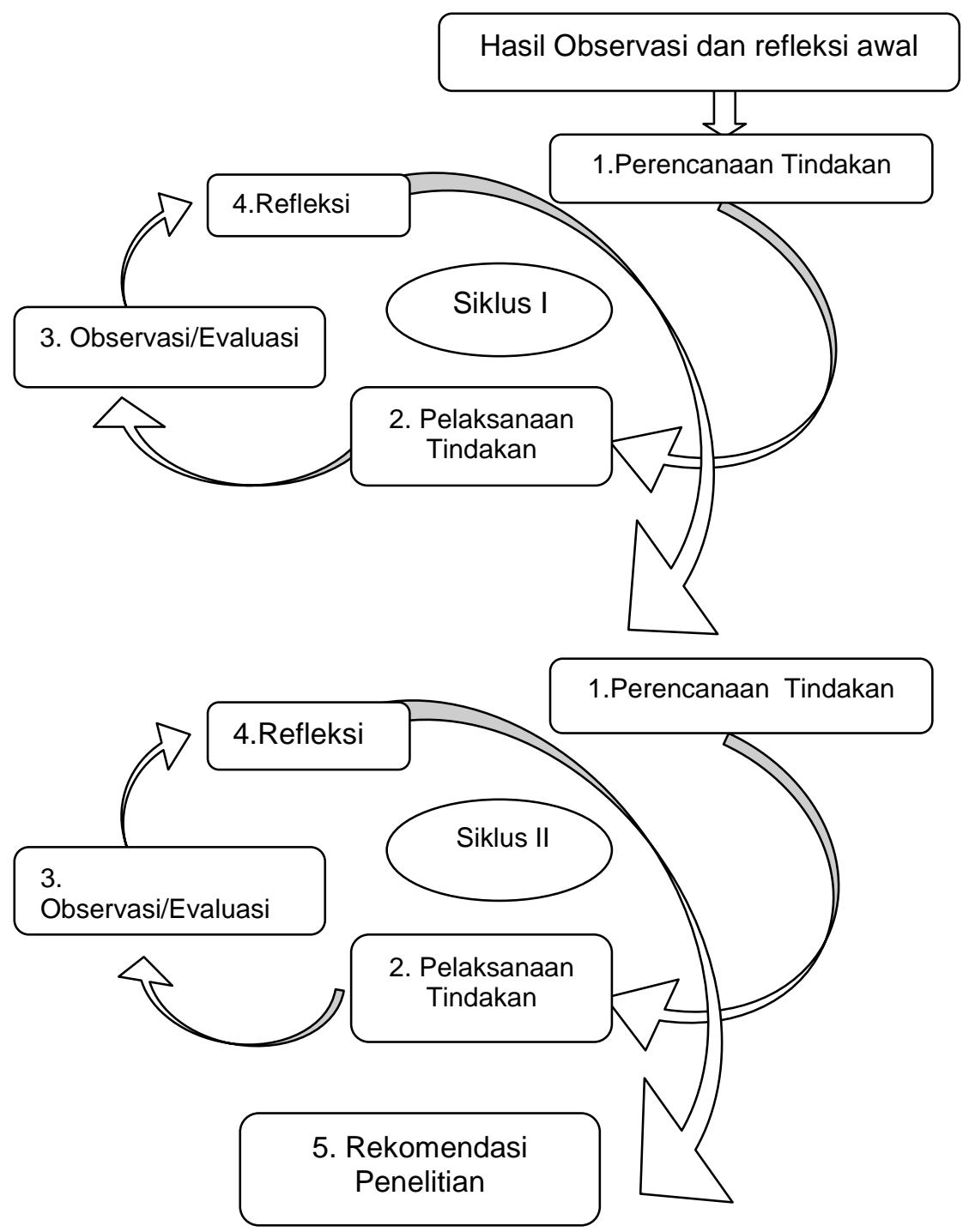

Gambar 1. Siklus Peneitian

Subyek dalam penelitian ini adalah siswa kelas X AP1 SMK Negeri 1 Sukasada, dengan jumlah 36 orang siswa perempuannya 16 dan laki laki nya 20 orang. Dan yang menjadi Objek penelitian tindakan kelas ini adalah hasil belajar PPKn siswa.

Metode pengumpulan data yang digunakan dalam penelitian ini yaitu berupa Tes. Tes yang digunakan adalah tes uraian. Adapun materi yang dijadikan poin di dalam PTK ini adalah Wawasan Nusantara dalam konteks Negara kesatuan Republik Indonesia 
Data yang dikumpulkan dalam penelitian ini dianalisis dengan menggunakan analisis kuantitatif dan kualitatif. Data hasil belajar PPKn siswa dianalisis secara deskriptif berdasarkan skor rata-rata $(\bar{X})$.

Rumus yang digunakan untuk mengukur skor kemampuan PPkn adalah:

$$
\bar{X}=\frac{\sum X}{N}
$$

(Arikunto, 2016)

Keterangan:

$$
\begin{array}{ll}
\bar{X} & =\text { rata-rata kelas } \\
\sum_{\mathrm{N}} X & =\text { jumlah skor yang dicapai seluruh siswa } \\
& =\text { banyak siswa }
\end{array}
$$

Ketuntasan aspek kognitif siswa dapat di tentukan dengan menggunakan daya serap siswa (DSS) dan ketuntasan klasikal (KB).

$$
\begin{aligned}
& \text { DSS }=\frac{\text { Jumlah total skor yang dicapai siswa }}{\text { Jumlah total skor maksimum }} \times 100 \% \\
& \mathrm{~KB}=\frac{\text { Banyak siswa yang tuntas }}{\text { banyak siswa yang ikut tes }} \times 100 \%
\end{aligned}
$$

Untuk memenuhi kriteria tersebut maka skor data yang diperoleh harus dikonversi ke skala 100 dengan rumus seperti berikut ini.

$$
\text { Nilai }=\frac{\text { Skor yang diperoleh siswa }}{\text { Skor maksimum }} \times 100
$$

Pedoman penggolongan hasil belajar mata pelajaran PPKn siswa terhadap penerapan model pembelajaran role playing dinyatakan dengan Tabel 2 berikut:

Tabel 2. Pedoman Penggolongan Kemampuan PPKn

\begin{tabular}{ll}
\hline \multicolumn{1}{c}{ Persentase Skor Total siswa } & \multicolumn{1}{c}{ Katagori Kemampuan siswa } \\
\hline $94-100$ & Sangat Baik \\
$84-93$ & Baik \\
$78-83$ & Cukup \\
$69-77$ & Kurang Baik \\
$0-68$ & Sangat Kurang Baik \\
\hline
\end{tabular}

Penelitian Tindakan Kelas ini dikatakan berhasil jika terjadi peningkatan hasil belajar PPKn siswa sesuai dengan target yang ditetapkan. Target keberhasilan penelitian ini adalah siswa mampu mencapai skor rerata yaitu minimal 78 , daya serap siswa minimum $78 \%$, dan ketuntasan klasikal minimum $78 \%$.

\section{Hasil dan Pembahasan}

Berdasarkan hasil pengamatan terhadap daftar nilai siswa kelas X AP1 SMK Negeri 1 Sukasada Tahun Pelajaran 2017/2018 semester genap, terungkap bahwa hasil belajar PPKn masih rendah. Ini terlihat pada data hasil belajar PPKn siswa kelas X AP1 SMK Negeri 1 Sukasada

Pada siklus I diperoleh data hasil belajar PPKn siswa kelas X AP1 SMK Negeri 1 Sukasada, rerata kemampuan PPKn yang dicapai besarnya 74,8 yang berada pada kategori kurang dan belum melampaui target yang diinginkan oleh peneliti, sedangkan angka ketuntasan klasikalnya sebesar $30 \%$ yang tergolong masih belum tuntas. Kemampuan PPKn siswa pada 
siklus I ini belum mencapai target yang ditetapkan oleh peneliti, yang menargetkan dalam penelitian ini adalah sebesar 78 , daya serap siswa $\geq 78 \%$, dan ketuntasan klasikal $\geq 90 \%$. Sehingga penelitian ini mesti dilanjutkan pada siklus ke II.

Pada Siklus II diperoleh data sebagai berikut, rerata hasil belajar PPKn yang dicapai besarnya 85,81 yang berada pada kategori baik, yang tergolong tuntas. Kemampuan PPKn siswa pada siklus II ini sudah mencapai target yang ditetapkan oleh peneliti, yang menargetkan kemampuan PPKn minimal 78, daya serap siswa $\geq 78 \%$, dan ketuntasan klasikal $\geq 90 \%$.

Berdasarkan permasalahan yang penulis temui di lapangan pada awal observasi, dapat disimpulkan keaktifan dan bahwa hasil belajar siswa kelas X AP2 SMK Negeri 1 Sukasada pada tengah semester genap tahun akademik 2017/2018 masih jauh dari harapan. Ini dikarenakan tingkat keaktifan dan hasil belajar siswa masih rendah, penyebab rendahnya tingkat keaktifan dan hasil belajar siswa dipengaruhi oleh beberapa faktor, diantaranya: 1) Pelajaran berjalan membosankan, 2) Siswa menjadi pasif dan hanya menulis saja, 3) Karena siswa pasif maka pengetahuan yang di peroleh mudah dilupakan, 4) Siswa hanya belajar dengan cara menghapal dan tanpa memahami makna dari pembelajaran itu sendiri.

Untuk mengatasi berbagai temuan di atas, diperlukan pembelajaran yang dapat membuat keaktifan dan meningkatkan hasil belajar siswa Diharapkan guru menerapkan pendekatan model Role Playing, menurut Hamalik (2008:214) melalui Role Playing siswa dapat bertindak dan mengekspresikan perasaan serta pendapat tanpa kekhawatiran mendapat sanksi. Selain itu bermain peran memungkinkan para siswa mengidentifikasi situasi-situasi dunia nyata dengan ide-ide orang lain, maka peran guru sebagai pendidik perlu mendapatkan perhatian khusus di dalam penerapan model pembelajaran yang tepat, karena dengan penerapan model pembelajaran yang tepat akan dapat memacu semangat para siswa dalam mengikuti pembelajaran dan mendorong siswa mengembangkan pengetahuan yang dimiliki dengan pengetahuan yang didapatkan dari sekolah sehingga para siswa akan bersikap aktif dalam mengikuti pelajaran khususnya pelajaran PPKn.

Model Role Playing merupakan suatu cara penguasaan bahan-bahan pelajaran melalui pengembangan imajinasi dan penghayatan siswa. Pengembangan imajinasi dan penghayatan dilakukan siswa dengan memerankannya sebagai tokoh hidup atau benda mati. Permainan ini pada umumnya dilakukan lebih dari satu orang, hal itu bergantung kepada yang diperankan.

Berdasarkan beberapa pendapat di atas, maka dapat disimpulkan bahwa model pembelajaran Role Playing merupakan jenis model pembelajaran yang aktif dan menyenangkan. Penerapan model pembelajaran role playing dapat meningkatkan hasil belajar dengan memainkan peran tokoh tokoh yang ada dalam hubungan sosial, sehingga siswa dapat melibatkan keterampilan emosional sebagai orang lain di luar dirinya Bedasarkan hal tersebutlah, bahwa dengan penerapan model pembelajaran kooperatif tipe TGT dapat meningkatkan hasil belajar PPKn siswa kelas X AP 1 SMK Negeri 1Sukasada tahun pelajaran $2017 / 2018$.

\section{Kesimpulan}

Penerapan model pembelajaran Kooperatif tipe Role Playing dapat meningkatkan hasil belajar PPKn siswa kelas X AP1 SMK Negeri 1 Sukasada tahun pelajaran 2017/2018 semester genap. Hal ini dapat dilihat dari hasil belajar PPKn siswa pada data siklus I dengan rata-rata sebesar 75,0 yang termasuk ke dalam kategori kurang. Sedangkan pada siklus II rata-rata PPKn siswa sebesar 85,8 yang termasuk ke dalam kategori Baik dan ketuntasan klasikal sebesar $100 \%$ dari 36 siswa.

\section{Daftar Rujukan}

Angkowo \& Kosasih. 2007. Optimalisasi Media Pembelajaran Mempengaruhi Motivasi Hasil Belajar dan Kepribadian. PT Grasindo. Jakarta.

Danim, Sudarwan. 2002. Menjadi Peneliti Kualitatif. Bandung: CV. Pustaka Setia.

Dewi, Ratna Puspita. 2014. Penerapan Metode Pembelajaran Role Playing untuk Meningkatkan Motivasi dan Hasil Belajar Siswa pada Pembelajaran IPS di Sekolah Dasar. JPGSD Volume 02 Nomor 03 Hal. 1-11. https://media.neliti.com/media/publications/. Diakses 22 Mei 2019. 
Ernani, Ahmad Syarifuddin. 2016. Pengaruh Metode Role Playing Terhadap Keterampilan Berbicara Siswa Pada Mata Pelajaran Bahasa Indonesia Kelas V di Madrasah Ibtidaiyah Wathoniyah Palembang. Jurnal IImiah PGMI Volume 2 Nomor 1 Hal. $29-42$. http://jurnal.radenfatah.ac.id/index.php/. Diakses 22 Mei 2019.

Faturahman, dkk. 2012. Pengantar Pendidikan. Jakarta: PT. Prestasi Pustakarya Hamzah, B. Uno. 2007. Teori Motivasi dan Pengukurannya Analisis dibidang Pendidikan. Bumi Aksara. Jakarta.

Hanafiah.2010. Motivasi Belajar Siswa. Semarang: Cakra Press.

Iskandar. 2009. Penelitian Tindakan Kelas. Ciputat: GP. Press.

Kertih. I Wayan. 2015. Perangkat Pembelajaran PPKn: Perencanaan dan Pengembangan. Yogyakarta: Media Akademi.

Kristin, Firosalia. 2018. Meta-Analisis Pengaruh Model Pembelajaran Role Playing terhadap Hasil Belajar IPS. Jurnal Refleksi Edukatika 8 (2) Hal. 171-176. http://jurnal.umk.ac.id/index.php/RE. Dikakses 22 Mei 2019.

Kunandar. 2010. Langkah Mudah Penelitian Tindakan Kelas sebagai Pengembangan Profesi Guru. Rajagrafindo Persada. Jakarta.

Lestari, Raran Suci. 2014. Pengaruh Penggunaan Model Role Playing dengan Media Video terhadap Hasil Belajar IPS (Studi Eksperimen Pada Siswa Kelas V SDN Gondangwetan 1 Pasuruan). Pedagogy Vol. 02 No. 01 Hal. 25-32. http://library.um.ac.id/freecontents/index.php/. Diakses 22 Mei 2019.

Nuliandini, Putri, Wirda Hanim, Atiek Sismiati S. 2016. Pengaruh Role Play dalam Konseling Kelompok untuk Menurunkan Tingkat Bullying Siswa (Studi Kuasi Eksperimen terhadap Siswa Kelas XII di SMK Negeri 41 Jakarta). Jurnal Bimbingan Konseling 5 (1) Hal. 8186. http://journal.unj.ac.id/unj/index.php/ . Diakses 22 Mei 2019.

Nurhasanah, Ismawati A., Atep Sujana, Ali Sudin. 2016. Penerapan Metode Role Playing untuk Meningkatkan Hasil Belajar Siswa pada Materi Hubungan Mahluk Hidup dengan Lingkungannya. Jurnal Pena Ilmiah Vol. 1 No. 1 Hal. 611-620. http://ejournal.upi.edu/index.php/. Diakses 22 Mei 2019.

Sari Adnyani, Ni Ketut. 2014. Pembelajaran, Berbasis Masalah Untuk Meniningkatkan Motivasi dan Hasil Belajar Mahasiswa. Jurnal Pendidikan dan Pengajaran (JPP) UNDIKSHA ISSN 2301-7821 Jilid 47, Nomor 2-3 Oktober 2014.

Sari, Malda. 2017. Meningkatkan Hasil Belajar Siswa Dengan Menggunakan Metode Role Playing Pada Pelajaran IPS. http://semnasfis.unimed.ac.id/wp-content/uploads/. Diakses 22 Mei 2019.

Sambeng, Agus. .2010.. Upaya Guru Dalam Meningkatkan Motivasi Belajar. Siswa.

Sardiman. 2010. Interaksi \& Motivasi Belajar Mengajar. Raja Grafindo Persada. Jakarta. Undang-Undang Republik Indonesia No. 20 tentang Sistem Pendidikan Nasional. Depdiknas. Jakarta.

Tarigan, Arleni. 2016. Penerapan Model Pembelajaran Role Playing untuk Meningkatkan Hasil Belajar IPS Siswa Kelas III SD Negeri 013 Lubuk Kembang Sari Kecamatan Ukui. Jurnal Primary Program Studi Pendidikan Guru Sekolah Dasar Fakultas Keguruan dan IImu Pendidikan Universitas Riau Vol. 5 No. 3 Hal. 102-112. https://media.neliti.com/media/publications/. Diakses 22 Mei 2019.

Tuken, Ritha. 2016. Peningkatan Hasil Belajar Siswa pada Mata Pelajaran Pkn Melalui Pembelajaran Kooperatif tipe Role Playing di Kelas VI SDN IV Kota Parepare. Jurnal 
JP2, Vol 2 No 1, Tahun 2019

p-ISSN : 2614-3909 e-ISSN : 2614-3895

Publikasi Pendidikan Volume VI Nomor 2 Juni 2016. http://ojs.unm.ac.id/index.php/pubpend. Diakses 22 Mei 2019.

Yanto, Ari. 2015. Metode Bermain Peran (Role Playing) untuk Meningkatkan Hasil Belajar Siswa pada Mata Pelajaran IPS. Jurnal Cakrawala Pendas Volume I No. 1 Hal.53-57. https://media.neliti.com/media/publications/. Diakses 22 Mei 2019.

Zuaherini, Ahmad. 2000. Interaksi dan Motivasi Belajar Mengajar. 